Institute of $\mathbf{F}_{\text {ood and }} \mathbf{A g r i c u l t u r a l}_{\text {ciences }}$

\title{
Como Realizar un Plan de Gastos - Séptimo Paso: Siga su Plan ${ }^{1}$
}

Nayda I Torres ${ }^{2}$

Usted puede crear un nuevo plan de gasto modificando su plan actual. Si usted puede aumentar sus ingresos, agregue la cantidad a la hoja de ingresos del Paso 4. Si usted puede reducir sus gastos, reste la cantidad de las hojas de gasto en el Paso 5. Compare sus nuevos ingresos totales y sus nuevos gastos totales. Quizás tenga que cambiar sus hábitos de gastos y ahorro para alcanzar sus nuevas metas.

Guarde un archivo financiero con sus ingresos para que usted pueda ahorrar lo suficiente para pagar sus facturas a tiempo y empezar a ahorrar para alcanzar sus metas de corto y largo plazo. Si usted no tiene una cuenta de ahorro o cuenta corriente, consiga una. Si no puede, distribuya su dinero en diferentes sobres para cada gasto. Saque dinero de los sobres cuando necesite pagar alguna factura.

\section{Consejos Útiles}

- Concéntrese en sus metas a corto y largo plazo. Si le ayuda a alcanzar sus metas, hágalo. ¡Si no, no lo haga!

- Mantenga el buen hábito de guardar y organizar sus archivos financieros.

- Conserve archivos de gastos que sean simples y fácil de entender.

- Encuentre un sistema de guardar y archivar datos que sea simple y eficaz.

- Cuide sus pertenencias y cuídese usted también.

- Elimine gastos innecesarios.

1. Este documento es la Hojuela FCS7173-Span, una serie del Departamento de Ciencias de la Familia, Juventud y Comunidad, Servicio de Extensión Cooperativa de Florida, Instituto de Alimentos y Ciencias Agrícolas, Universidad de Florida. Fecha de publicación: Octubre 2002. Por favor visite el web de EDIS http://edis.ifas.ufl.edu

2. Escrito por Nayda I. Torres, Profesora, Familia y Economía del Consumidor y la versión en Inglés ha sido revisada por Josephine Turner, CFP, Profesora, Familia y Economía del Consumidor, Servicio de Extensión Cooperativa, Departamento de Ciencias de la Familia, Juventud y Comunidad, Instituto de Alimentos y Ciencias Agrícolas, University of Florida, Gainesville, 32611. Traducido por: Sergio Romero.

El Instituto de Alimentos y Ciencias Agrícolas es un patrono que ofrece igualdad de oportunidad de empleo, autorizado a proveer investigación, información educativa y otros servicios a individuos y a instituciones que ejerzan sus funciones sin tomar en consideración raza, color, sexo, edad, incapacidad o nacionalidad. Para información sobre como obtener otras publicaciones del Servicio de Extensión, comuníquese con la Oficina del Servicio de Extensión Cooperativa de su Condado. Servicio de Extensión Cooperativa de Florida / Instituto de Alimentos y Ciencias Agrícolas / Universidad de Florida, Christine Taylor Waddill, Decano 
- Arregle o descarte las cosas que no funcionan correctamente.

- No compre productos nuevos. Si es posible, cómprelos usados o fabríquelos usted mismo

- Compre en volumen. Comparta los costos con vecinos o familiares.

- Guarde dinero para sus facturas y sus metas.
- Pague sus facturas a tiempo.

- Siga su plan de mes en mes.

- Revise su plan todos los meses.

- Prémiese haciendo cosas que no cuesten dinero. 